\title{
Induced Chitinase and Chitosanase Activities in Turmeric Plants by Application of $\beta$-D-Glucan Nanoparticles
}

\author{
Sathiyanarayanan ANUSUYA, Muthukrishnan SATHIYABAMA*
}

Bharathidasan University, Department of Plant Science, Tiruchirappalli-620 024, Tamilnadu, India; sathiyabamam@yahoo.com (*orrespondingauthor)

\begin{abstract}
The chitinase and chitosanase activities after $\beta$-D-glucan nanoparticle (GNP) application turmeric plants (leaves and rhizomes) were measured. Foliar spray of GNP $(0.1 \%$, w/v) elicited marked an increase in the activity levels of chitinases and chitosanases. Such a growth of enzyme activities was enhanced by subsequent spraying GNP on turmeric leaves at regular intervals. Application of $\beta$-D-glucan nanoparticles enhanced the level of defense related enzymes in leaves and rhizomes, which correlated well with new isoforms of the enzymes. Qualitative differences in isoforms of these defense enzymes were investigated during the hereby time-course study. In general, the expression of chitinase activity was comparatively lower in rhizomes than in leaves. Chitinase and chitosanase activity reached maximum values during the $7^{\text {th }}$ month. Exploiting the nanoparticle (derived from natural polysaccharide) potential may refer to induce defense enzymes that may diminish the use of toxic chemicals for disease control. Thus the use of nanoparticles could be proposed as an alternative, non-conventional and ecologically friendly approach for plant protection and hence for sustainable agriculture.
\end{abstract}

Keywords: Curcuma, defense enzyme, disease control, enzyme, nanotechnology

\section{Introduction}

Nanotechnology is gaining significant promise in agricultural sector for increased protection (Baruah and Dutta, 2009; Nair et al., 2010; Ghormade et al., 2011). Nanoparticles prepared from biopolymers or natural sources possess advantages such as availability from replenishable agricultural resources, biocompatibility, biodegradability and ecological safety (Ghormade et al., 2011). Reports show that $\beta$-glucans play an important role during pathogen infection by inducing systemic resistance in plants (Yamaguchi et al., 2000; Sriram et al., 2003; Shinya et al., 2006; Shetty et al., 2009). However, the size of the glucan limits its wide spectrum application, since plant cell wall acts as a barrier for easy entry of any external agent.

Higher plants have the ability to initiate various defense mechanisms when they are exposed to biotic and abiotic stimuli. Chitinases and chitosanases are hydrolytic enzymes induced during biotic and abiotic stress (Mauch et al., 1988; Grenier and Asselin, 1990; Graham and Sticklens, 1994). Also, the substrates chitin, chitosan and $\beta-1,3$ glucan are the major cell wall components of phytopathogenic fungi.

Hence, this study aimed to evaluate the potential of $\beta-\mathrm{D}$ glucan nanoparticles for induction of chitinases and chitosanases in turmeric plants; the experiment developed under glass house condition.

\section{Materials and Methods}

Rhizomes of Curcuma longa (syn. C. domestica) cultivar 'Erode local' (susceptible) were obtained from farmer's field at Erode, Tamil Nadu, India.
GNP preparation and foliar application of the nanoparticles

GNP was prepared as described by well established protocol (Anusuya and Sathiyabama, 2014). Rhizomes were thoroughly washed with running tap water thrice, followed by glass distilled water; surface was sterilized by immersion in sodium hypochlorite $0.001 \%$ (v/v) solution for 15 minutes, followed by several rinses with sterile distilled water. The rhizomes (2-3 rhizomes, each with 3 nodes $)$ were planted in earthen pots $(27 \mathrm{~cm}$ diameter, $26 \mathrm{~cm}$ height) containing soil and manure, being maintained under glass house condition. GNP $(0.1 \%$, w/v) were applied to 30 day old plants (5 $\mathrm{ml} /$ plant) by foliar spray method, at a regular interval of 30 days, up to 210 days, as reported earlier (Anusuya and Sathiyabama, 2015). Water sprayed plants served as control. The leaves were removed after 210 days and the rhizomes were left for another 30 days before harvest. For each experiment, 30 plants were used and replicated thrice.

\section{Protein extraction and enzyme assays}

Leaves and rhizomes were collected from control and treated turmeric plants at regular intervals and used for extraction. The samples $(1 \mathrm{~g} / 2 \mathrm{ml})$ were homogenized with potassium phosphate buffer (0.02 $\mathrm{M}, \mathrm{pH} 7.6)$ and centrifuged for $10 \mathrm{~min}$ at $4{ }^{\circ} \mathrm{C}$. The clear supernatant was used as source of protein, for enzymes.

Chitinase (EC 3.2.1.14) activity was assayed by the method of Reissig et al. (1955) using colloidal chitin as substrate. $\mathrm{N}$-acetylglucosamine was used as standard. One 
296

unit of chitinase was defined as the amount of enzyme that liberated $1 \mu \mathrm{M}$ of $\mathrm{N}$-acetylglucosamine per minute under assay condition.

Chitosanase activity (EC 3.2.1.132) was determined by measuring the reducing sugars produced from chitosan. These sugars were estimated by Nelson (1944) and Somogyi (1952), using chitosamine $\mathrm{HCl}$ as standard. One unit of chitosanase was defined as the amount of enzyme that liberated $1 \mu \mathrm{M}$ of reducing sugar, as chitosamine, per minute, under assay condition.

\section{Gel electrophoresis}

Protein samples $(40 \mu \mathrm{g})$ from leaves and rhizomes of control and treated plants were separated on SDS-PAGE (10\% separation gel) by the method of Laemmli (1970) along with standard marker protein from Bio Rad Chem Co USA. For chitinase localization, $0.1 \%$ (w/v) glycol chitin was included in the separation gel. After electrophoresis, the gel was stained with calcofluor white M2R according to the procedure of Trudel and Asselin (1989). Chitosanase localization was carried out according to the method of Grenier and Asselin (1990) whereas the separation gel contained $0.02 \%$ glycol chitosan. After electrophoresis, the gel was stained with $0.02 \%(\mathrm{w} / \mathrm{v})$ coomassie brilliant blue.

\section{Statistical analysis}

All data were subjected to one-way analysis of variance to determine the significance of individual differences at $\mathrm{p}<$ 0.01 and 0.05 levels. All statistical analysis was conducted using SPSS 16 software support.

\section{Results and Discussion}

In the present study, it was examined the effect of GNP treatment and the ability to trigger induction of defence enzymes such as chitinase and chitosanase in turmeric plants. The basal level of chitinase activity was recorded in control and treated plants. Leaves of GNP treated plants showed significant increase in chitinase activity when compared to control. The maximum chitinase activity was observed in the $7^{\text {th }}$ month (Fig. 1a). A similar pattern of increase in chitinase activity was observed in rhizomes of treated plants (Fig. 1a). The chitinase activity was higher in GNP treated plants, whereas control plants showed the least activity.

Significant difference was observed in the chitinase banding pattern among leaves of control and treated plants. Constitutive chitinase isoforms with molecular mass $60,50,36.8$ and $19.3 \mathrm{kDa}$ were induced in the $1^{\text {st }}$ and $2^{\text {nd }}$ month after GNP treatment. In the $2^{\text {nd }}, 3^{\text {rd }}$ and $4^{\text {th }}$ month, a new isoform $(77.8 \mathrm{kDa})$ was observed in GNP treated plants. In addition to this, $22 \mathrm{kDa}$ chitinase isoform was observed in the $3^{\text {rd }}, 4^{\text {th }}$ and $5^{\text {th }}$ month. In months 4,6 and 7, $32 \mathrm{kDa}$ isoform was observed in GNP treated plants. Apart from this, GNP treated plants showed a new isoform of molecular mass, respectively 34 $\mathrm{kDa}$, in the $7^{\text {th }}$ month (Fig. 1b).

In general, the expression of chitinase activity was comparatively lower in rhizomes than in leaves. In the $1^{\text {st }}$, $2^{\text {nd }}$ and $3^{\text {rd }}$ month, $34 \mathrm{kDa}$ new chitinase isoform was observed in GNP treated plants. Another new chitinase isoform of molecular mass, $77.8 \mathrm{kDa}$, was observed in months 1, 5 and 8 respectively. Apart from this, GNP

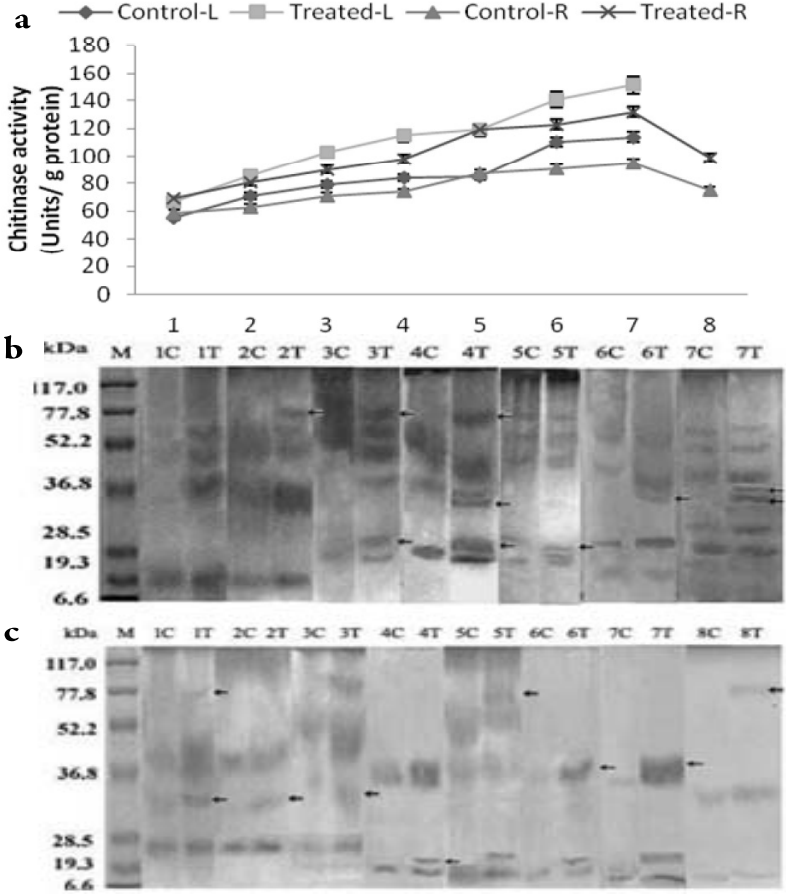

Fig. 1. Chitinase activity (a) in control and treated turmeric plants (LLeaf; R- Rhizome); Localization of chitinase isoforms in leaves (b) and rhizomes (c) of turmeric plants on SDS-PAGE (10\%)

M - Marker protein standard (Bio Rad Chem. Co., USA); C - Control; T Treated; 1 to 8 - age of the plant in month. Molecular weight of marker protein: 117.0 kDa- $\beta$-Galactosidase; $77.8 \mathrm{kDa}$ - BSA; $52.2 \mathrm{kDa}$ - Ovalbumin; $36.8 \mathrm{kDa}$ Carbonic anhydrase; $28.5 \mathrm{kDa}$ - Soybean trypsin inhibitor; $19.3 \mathrm{kDa}$ Lysozyme; $6.6 \mathrm{kDa}$ - Aprotinin.
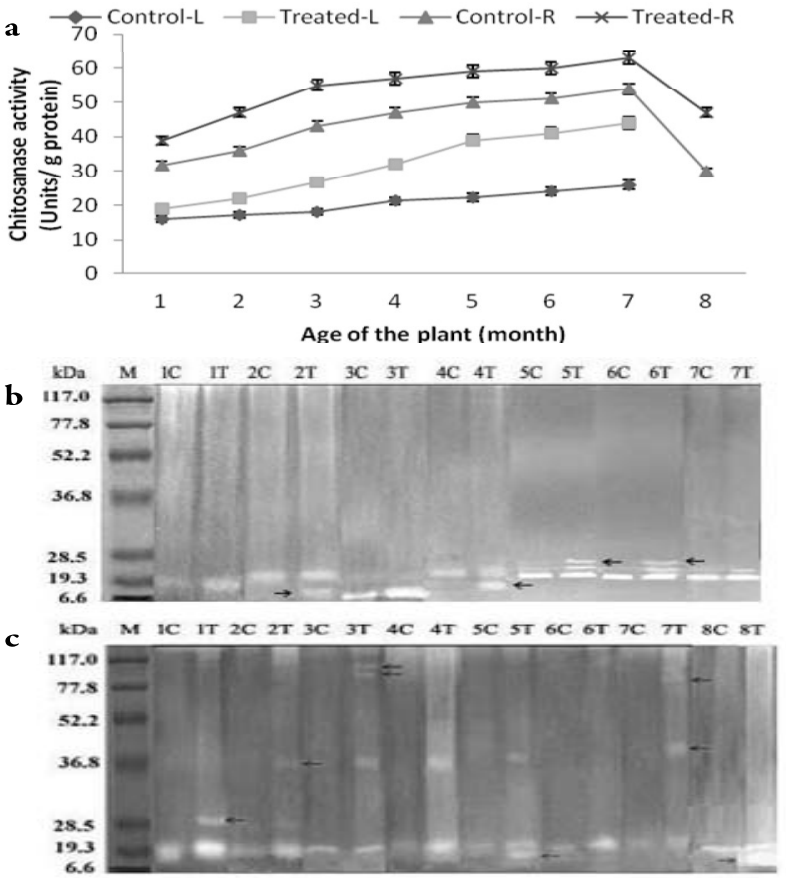

Fig. 2. Chitosanase activity (a) in control and treated turmeric plants (LLeaf; R-Rhizome); Localization of chitosanase isoforms in leaves (a) and rhizomes (b) of turmeric on SDS-PAGE (10\%)

M-Marker protein standard (Bio Rad Chem Co., USA); C-Control; T-Treated; 1 to 7 - age of the plant in month. Molecular weight of marker protein: $117.0 \mathrm{kDa}-\beta$-Galactosidase; $77.8 \mathrm{kDa}$ BSA; $52.2 \mathrm{kDa}$ - Ovalbumin; $36.8 \mathrm{kDa}$ - Carbonic anhydrase; $28.5 \mathrm{kDa}$ - Soybean trypsin inhibitor; $19.3 \mathrm{kDa}$-Lysozyme; $6.6 \mathrm{kDa}$-Aprotinin. 
treated plants showed new chitinase $22 \mathrm{kDa}$ isoform from $4^{\text {th }}$ to $7^{\text {th }}$ month. Induced isoform of molecular mass $36.8 \mathrm{kDa}$ was observed in $6^{\text {th }}$ and $7^{\text {th }}$ month of GNP treated plants (Fig. 1c).

An increase in chitosanase activity was observed in treated plants compared to control. Chitosanase activity showed a gradual increase in both leaves and rhizomes of treated plants and reached its peak in the $7^{\text {th }}$ month (Fig. $2 a)$. The chitosanase activity was comparatively higher in rhizomes than in the leaves of turmeric plants.

As in Fig. 2b, $19.3 \mathrm{kDa}$ chitosanase isoform was observed in the $1^{\text {st }}$ month leaves of control and treated plants and remained up to the $7^{\text {th }}$ month. GNP treated plants revealed a new chitosanase isoform of molecular mass $6.6 \mathrm{kDa}$ in the $2^{\text {nd }}$ month. In the $4^{\text {th }}$ month, another new constitutive chitosanase isoform of molecular mass $15 \mathrm{kDa}$ was observed in GNP treated plants. During the $5^{\text {th }}$ and $6^{\text {th }}$ month, GNP treated plants showed new chitosanase isoform of $25 \mathrm{kDa}$. Induced chitosanase isoform of $28.5 \mathrm{kDa}$ was observed in the $7^{\text {th }}$ month (Fig. $2 b)$.

Rhizomes of GNP treated plants revealed new chitosanase isoforms with molecular masses of 28.5 and $36.8 \mathrm{kDa}$ in the $1^{\text {st }}$ and $2^{\text {nd }}$ month respectively. The 36.8 $\mathrm{kDa}$ isoform remains until the $5^{\text {th }}$ month. In the $3^{\text {rd }}$ month two new isoforms 95 and $110 \mathrm{kDa}$ were observed. In addition, GNP treated plants showed a new isoform of $15 \mathrm{kDa}$ in the $5^{\text {th }}$ month. Two new chitosanase isoforms of molecular masses 90 and $48 \mathrm{kDa}$ were observed in $7^{\text {th }}$ month in GNP treated plants. Another new chitosanase isoform of molecular mass $8 \mathrm{kDa}$ was observed in the $8^{\text {th }}$ month (Fig. 2 c).

In the present study, it had been evaluated the effect of foliar application of $\beta$-D-glucan nanoparticles on defense enzymes' induction. Plant cell wall normally acts as a barrier for easy entry of any external agents, only nanoparticles, smaller than the pore diameter of the cell wall, can easily pass through and reach the plasma membrane (Moore, 2006; Navarro et al., 2008). They may also cross the membrane using embedded transport carrier proteins or through ion channels. In the cytoplasm, the nanoparticles may bind with different cytoplasmic organelles and interfere with the metabolic processes at that site (Jia et al., 2005). When nanoparticles are applied on leaf surfaces, they also enter through the stomatal openings or through the bases of trichomes and then translocated to various tissues (Fernandez and Eichert, 2009; Uzu et al., 2010; Anusuya and Sathiyabama, 2015).

The interaction of plant cell with the nanoparticles resulted in modification of plant gene expression and associated biological pathways were reported (Nair et al., 2010). Chitinase and chitosanase play a role in defense against invading pathogens because of their potential to hydrolyze fungal cell wall polysaccharides (Pozo et al., 1998).

\section{Conclusions}

Application of $\beta$-D-glucan nanoparticles enhanced the level of defense related enzymes such as chitinases and chitosanases in leaves and rhizomes, which correlated well with new isoforms of the enzymes. Results of the hereby study suggested that the $\beta$-D-glucan nanoparticles application showed significant impact on induction of defense related enzymes, such as chitinases and chitosanases, under glass house condition. However, further work is necessary to identify the genes which undergo up regulation due to application of $\beta$-D-glucan nanoparticles to turmeric plants. Nanoparticle based formulations required in low volume with high value application makes the control more acceptable than conventional pesticides, which have negative environmental impact. Hence, bio-based nanoparticle formulations could have great potential as novel agrochemicals with high specificity and improved functions.

\section{Acknowledgements}

The authors are grateful to Tamil Nadu State Council of Science and Technology (TNSCST/S\&T Project/AS/2011-12/2118) for financial support and university authorities of Bharathidasan University, Tiruchirappalli, Tamil Nadu for providing facilities.

\section{References}

Anusuya S, Sathiyabama M (2015). Foliar application of $\beta$-Dglucan nanoparticles to control rhizome rot disease of turmeric. International Journal of Biological Macromolecules 72:1205-1212.

Anusuya S, Sathiyabama M (2014). Preparation of $\beta$-D-glucan nanoparticles and its antifungal activity. International Journal of Biological Macromolecules 70:440-443.

Baruah S, Dutta J (2009). Nanotechnology applications in pollution sensing and degradation in agriculture: a review. Environmental Chemistry Letters 7:191-204.

Fernandez V, Eichert T (2009). Uptake of hydrophilic solutes through plant leaves: current state of knowledge and perspectives of foliar fertilization. Critical Reviews in Plant Sciences 28:36-68.

Ghormade V, Mukund VD, Kishore MP (2011). Perspectives for nano-biotechnology enabled protection and nutrition of plants. Biotechnology Advances 29(6):792-803.

Graham LS, Sticklen MB (1994). Plant chitinases. Canadian Journal of Botany 72(8):1057-1083.

Grenier J, Asselin A (1990). Some pathogenesis-related proteins are chitosanases with lytic activity against fungal spores. Molecular Plant-Microbe Interactions 3(6):401417.

Jia G, Wang H, Yan L, Wang X, Pei R, Yan T, Zhao Y, Guo X (2005). Cytotoxicity of carbon nanomaterials: single-wall nanotube, multi-wall nanotube, and fullerene. Environmental Science \& Technology 39(5):1378-1383.

Laemmli UK (1970). Cleavage of structural proteins during the assembly of the head of bacteriophage $\mathrm{T}_{4}$. Nature 227:680-685.

Mauch F, Mauch-Mani B, Boller T (1988). Antifungal hydrolases in pea tissue II. Inhibition of fungal growth by combinations of chitinase and beta-1,3-glucanase. Plant Physiology 88(3):936-942. 
298

Moore MN (2006). Do nanoparticles present ecotoxicological risks for the health of the aquatic environment? Environment International 32(8):967-976.

Nair R, Varghese SH, Nair BG, Maekawa T, Yoshida Y, Sakthi Kumar D (2010). Nanoparticulate material delivery to plants. Plant Science 179(3):154-163.

Navarro E, Baun A, Behra R, Hartmann NB, Filser J, Miao AJ, Quigg A, Santschi PH, Sigg L (2008). Environmental behaviour and ecotoxicity of engineered nanoparticles to algae, plants and fungi. Ecotoxicology 17(5):372-386.

Nelson N (1944). A photometric adaptation of the Somogyi method for the determination of glucose. The Journal of Biological Chemistry 153(2):375-380.

Pozo MJ, Azcon-Aguilar C, Dumas-Gaudot E, Barea JM (1998). Chitosanase and chitinase activities in tomato roots during interactions with arbuscular mycorrhizal fungi or Phytophthora parasitica. Journal of Experimental Botany 49(327):1729-1739.

Reissig JL, Strominger JL, Leolori IF (1955). A modified colorimetric method for the estimation of $\mathrm{N}$-acetylamino sugars. The Journal of Biological Chemistry 217(2):959966.

Shetty NP, Jensen JD, Knudsen A, Finnie C, Geshi N, Blennow A, David B, Collinge, Jorgensen HJL (2009). Effects of $\beta$-1,3-glucan from Septoria tritici on structural defense responses in wheat. Journal of Experimental Botany 60:4287-4300.
Shinya T, Menard R, Kozone I, Matsuoka H, Shibuya N, Kauffmann S, Matsuoka K, Saito M (2006). Novel $\beta$ 1,3,1,6-oligoglucan elicitor from Alternaria alternata 102 for defense responses in tobacco. Febs Journal 273(11):2421-2431.

Somogyi M (1952). Notes on sugar determination. Journal of Experimental Botany 195:19-23.

Sriram S, Misra RS, Sahu AK, Maheshwari SK (2003). A cell wall glucan elicitor induces resistance in taro against Phytophthora leaf blight. Zeitschrift für Pflanzenkrankheiten und Pflanzenschutz/Journal of Plant Diseases and Protection 110(1):17-26.

Trudel J, Asselin A (1989). Detection of chitinase activity after polyacrylamide gel electrophoresis. Analytical Biochemistry 178(2):362-366.

Uzu G, Sobanska S, Sarret G, Munoz M, Dumat C (2010). Foliar lead uptake by lettuce exposed to atmospheric pollution. Environmental Science \& Technology 44(3):1036-1042.

Yamaguchi T, Yamada A, Hong N, Ogawa T, Ishii T, Shibuya $N$ (2000). Differences in the recognition of glucan elicitor signals between rice and soybean: $\beta$-glucan fragments from 